\title{
Bürokrasi, Kamu Personeli Ve Siyaset Arasındaki İlişkiler ${ }^{1}$
}

\author{
Relations Between Bureaucracy, Public Personnel and Politics
}

\author{
Lütfullah ÜN \\ Dr, İçişleri Bakanlı̆̆g \\ lutfullahun57@gmail.com \\ https://orcid.org/0000-0002-8764-5113
}

\author{
MakaleBaşvuruTarihi / Received: 24.06.2021 \\ Makale Kabul Tarihi / Accepted : 26.06.2021 \\ MakaleTürü / Article Type: AraştırmaMakalesi
}

AnahtarKelimeler

Bürokrasi, Kamu Personeli, Siyaset

Keywords:

Bureaucracy, Public Personnel, Politics

\section{ÖZET}

Siyasal düzlemde kaynağını haktan alan sistemler demokratik rejimlerdir. Bu rejimlerde gerek halkın verdiği oylarla başa geçen seçilmişlerin gerekse kamu hizmetini yerine getiren bürokrasi ve kamu personelinin halka hizmet etme amacıyla var oldukları kabul edilir. Seçilmişler belli dönemlerle yetkiyi halktan alıp halka hesap verirlerken, atanmışlar anayasa ve kanunlardan aldıklarl yetki ile belirli bir süreklilikte halka hizmet etmek üzere çalışırlar. Her iki kesim de halk için çalışıyor olsa da bürokrasi, kamu personeli ve siyaset ilişkilerinin sınırlarının ne olduğu veyahut nasıl olması gerektiği akademik, siyasal ve bürokratik hayatın tartışma konularından biri olagelmiştir. Demokratik ülkelerde seçilmişlerin atanmışlara üstünlügü̈nün temel bir ilke olduğu öteden beri kabul edilmektedir. Ancak aralarındaki ilişki tarihsel süreçte, ülkelerin koşullarında ve hükümet sistemlerinde pek çok farklı değerlendirme ve fiili durumla izah edilebilmektedir. Bu bağlamda çalışmanın konusu seçilmişler ve atanmışlar arasındaki bu ilişkinin hangi boyutlarda ve nasıl ele alınabileceğidir. Konuyu çok boyutlu ele alma açısından önemli olan bu çalışma, seçilmiş ve atanmışlar arasındaki ilişkinin objektif değerlendirilebilmesi için bakış açısı kazandırmak amaçlamaktadır.

\section{GİRiş}

Hükümet sistemleri, demokratik ülkelerde seçimler aracılığıyla oluşan siyasal alanın aktörlerinin hükümet haline gelerek icranın başına geçebilmeleri ve devlet mekanizmasını işletebilmeleri için bazı yapı ve düzenlemeleri öngörmektedir. Diğer bir ifade ile halkın demokratik iradesi seçimler yoluyla yasama ve yürütme (doğrudan ya da dolaylı olarak) organlarını tesis eder. Seçilerek hükümet etme iradesini elde eden siyasal aktörler her ne kadar bir önceki siyasal aktörlerle halef selef durumunda olsalar da, siyasal alana göre devlet

${ }^{1} \mathrm{Bu}$ çalışma, yazarın Prof. Dr. İlhan AKSOY danışmanlığında hazırladığı “Türkiye'de Hükümet Sistemlerinin Kamu Yönetimine Etkileri Bağlamında Cumhurbaşkanlığı Hükümet Sistemi” adlı doktora tezinden üretilmiştir. 
işleyişi olarak görece daha kalıcı durumda olan bir kamu bürokrasisi ile karşılaşırlar (Kaya, 1994). ${ }^{2}$ Bu anlamda yürütmenin siyasi tarafı ve karar organı olan hükümetle yönetim aygıtı olan bürokrasi, yapıları nedeniyle sürekli ve zorunlu bir ilişki içindedir. Kamu politikası oluşumuna ve siyasete yardımcı ve uygulayıcı olan bürokrasinin (özellikle üst düzey); toplumsal değişimi gerçekleştirme, yasamayı etkileme, bütçe ve kanun hazırlama (ve görüş bildirme), gerekli durumlarda bakanlar kuruluna katılma, kanunları yorumlama ve uygulama ile devletin güvenlik işlerini gerçekleştirme gibi işlevi vardır (Kaya, 1994: 10-11). Ayrıca bu araçsal yönlerinin yanı sıra bürokrasi birçok ülkede "ulus ve devlet inşa etme süreçlerinde" önemli roller de üstlenmiştir (LaPalombara, 1967: 22). Dolayısıyla bürokrasi, kamu politikaların belirlenmesi ve kamu hizmetlerinin sunulması sürecinde siyasetle iç içedir. Ancak bu içiçelik atanmışlarla seçilmişler veya uzmanlıkla temsili demokrasi ilkeleri çelişkilerinden kaynaklı olarak gerilimli olabilmektedir. Bu gerilim hükümetle bürokrasi, siyasetçiyle bürokrat (uzman), siyasal seçkinle bürokratik seçkin, seçilmiş kamu görevlisiyle atanmış kamu görevlisi çatışmalarında açıkça somutlaşmaktadır (Farazmand, 1997: 10-11). ${ }^{3}$ Bu ilişkinin doğru tesisi için ise bürokrasinin tarafsız olup olmamasına yönelik değerlendirmeler (olan veya olması gereken), bürokrasinin belirlenmesi, göreve getirilmeleri ve yüklenecek roller ile sistemin genel tasarımı önem arz etmektedir. Bu bağlamda çalışmanın konusu seçilmişler ve atanmışlar arasındaki bu ilişkinin hangi boyutlarda ve nasıl ele alınabileceğidir. Konuyu çok boyutlu ele alma açısından önemli olan bu çalışma, seçilmiş ve atanmışlar arasındaki ilişkinin objektif değerlendirilebilmesi için bakış açısı kazandırmak amaçlamaktadır. Çalışmanın hazırlanmasında derinlemesine literatür taramaları gerçekleştirilmiş olup, çalışmada çeşitli düşünürlerin görüşlerinde, devlet ve hükümet sistemlerinde bürokrasinin konumuna dair bulgu ve değerlendirmeleri içermektedir.

\section{BÜROKRASINIIN TARAFSIZLIĞI MESELESI}

Bürokratik hiyerarşide üst kademelere doğru yönetsel ve siyasal görev ayrımı giderek zorlaşmakta, tavsiye ve karar verme gibi işlevler birbiriyle karışmaktadır (Onaran, 1967: 7). Bu çalışma düzleminde gerek bürokrasi gerekse siyasal kesime yönelik olumlu ve/veya olumsuz birçok bakış açısı ve görüş bulunmaktadır. Örneğin Emre'ye göre (1996b: 72) üst düzey kamu görevlileri sahip oldukları uzmanlık bilgisi, yönetim deneyimi ve birikimlerini bir güç olarak kullanarak ve siyasal tercih konularında kendi ağırlıklarını koyarak siyasetçilerin alanlarına girebilirler. Bu yönüyle siyasal niteliği olan kişilerle üst düzey kamu yöneticileri arasındaki ilişki hemen hemen bütün ülkelerde kuşku ve güvensizlik atmosferinde gelişmiştir. ${ }^{4} \mathrm{Bu}$ atmosferde siyasetçiler, bürokratların kendilerine nazaran daha çok sahip oldukları bilgi ve uzmanlık tekellerini yıkmaya çalışsalar da onlardan gelecek bilgi ve yorumlara ihtiyaçları vardır. Peters'a göre (2001: 228-234) bu zorunluk çerçevesinde bürokrasi sonuçların sorumluluğuna katlanmaksızın kararların alınması için (bilerek veya bilmeyerek) yanlış, çarpık, eksik bilgi verebilir veya bilgiyi kamusal politikalar üzerinde mübadele aracı olarak kullanabilir. Bu noktada bürokrasiyi olumsuzlayan bir başka görüşe göre ise bürokrasinin gizli yapısı, kendisinde bulunan bilginin de muhafazası açısından siyasilere karşı avantaj sağlar. Bürokrasi doğal olarak bilgiden yoksun veya bürokrasinin çıkarıyla uyumlu parlamento veya politikacılar yeğler (Geerth \& Mills, 1977: 232-234).

İdarede alınan karar ile yapılan uygulamanın da aynı doğrultuda olup olmaması da bu tartışmanın bir parçasıdır. Peters'a göre (2001: 231) gerçek kamu politikası yasama ve yürütmenin beyan ettiği değil, bürokrasi eliyle uygulamaya geçirilendir. Bürokrasi hükümetin politikasının uygulamasını erteleyebilir, geciktirebilir veya süreçte kendi değerleri bağlamında yeniden yorumlayarak hükümetin benimsediklerinden uzak bir şekilde kendi çıkarları ile uyumlu hale getirebilir.

Diğer bir görüşe göre ise seçilmiş siyasiler ve atanmış bürokratların her ikisi de kamu görevlisi olsa da motivasyon ve davranışları farklıdır ve güç mücadelesi içindedirler. Bu noktada Niskanen (1971: 92), kamuya adanmışlığı devamlı surette sorgulanan bürokrasiye nazaran seçilmiş siyasilerin kamunun çıkarlarını daha doğru temsil ettiğini belirtmektedir. Emre'ye göre ise (2003: 186) çoğulcu demokrasi ilkesine uygun olarak halkın oyları ile seçilen ve siyasi tercihlerin temsilcisi olan siyasetçi, sahip olduğu gücü ve üstünlüğü kullanmak suretiyle bürokrasi ve kamu yönetimi üstünde sınırsız bir yetkiye ve yönetimin ussal işleyişine müdahil olabilme yetkisine haiz olduğunu düşünebilmektedir.

\footnotetext{
${ }^{2}$ Bu bürokratik yapı bünyesinde her çeşit siyasal düşünceye ve kökene haiz insan profilini barındırsa da, uzunca yıllar belli bir siyasi ve idari kültürün içerisinde kalmanın beraberinde getireceği asgari müştereklerde buluşan bürokratik kültür elde etmeleri kaçınılmazdır.

${ }^{3} \mathrm{Bu}$ çatışmada bürokrasinin güç kaynakları; bilgi ve uzmanlık, karar verme iktidarı (seçmen baskılarına duyarlı olmak zorunda değil), çıkar grupları gibi siyasal destekçileri, apolitik niteliği, kurumsal ideolojisi ve istikrarlı statüsü gibi durumlardır. Siyasi kurumların güç kaynağı ise bütçe yapma hakk1, yetki verme gücü ve halkı temsil etmeleriyle ilgilidir (Peters, 2010: 211-214). Siyasi kurumlar gücünü ve meşruiyetini halktan alırlar, bütçe yaparlar, "soruşturma, denetlemeler, seçim kampanyaları, parlamento tartışma ve görüşmeleri" gibi araçlarla bürokrasiyi denetlerler. Ayrıca siyasiler bürokrasi dışı uzman personel kadroları ve bilgi kaynaklarını elde tutarlar (Eryılmaz, 2015: 280)

${ }^{4}$ Emre (1996b: 11) bu kuşku ve güvensizliğin kaynağının çıkar ve rant paylaşımları, siyasi ve ideolojik, ırksal ve dinsel ayrım ve ayrilıklar olduğunu iddia etmektedir.
} 
$\mathrm{Bu}$ farklı bakış açılarının yanı sıra demokratik meşru usullerle hükümet olan siyasal irade ile teknik ve idari açıdan işi bilen bürokrasi arasında sistemin işleyişi için gerekli olan uyumun yakalanması açısından üç görüş ortaya çıkmaktadır.

Birinci görüşe göre bürokrasi ve siyaset arasında keskin bir ayrım yapılmalı, teknik bir alan olan idare siyasi partizanlıktan uzak tutulmalıdır (Wilson, 1961: 63-64). Devletin politika ve amaçlarını siyaset belirlemeli, yönetim ise bunları yerine getirecek eylemleri yürütmelidir (Goodnow, 1900; Demir, 2011: 67). Bu doğrultuda idare ve siyaset ayrımını benimseyen yazarlar; "siyasetin ülke yönetimi açısından esaslı tercihler ile uğraştığını ve büyük meselelere yönelik çözümleri saptadığını, idarenin ise teknik nitelikte olup siyaset dışı alanda çalıştığını (Güven, 1976: 51) savunmuşlardır. Bu anlamda bürokrasi, toplumsal sistemin düzenli ve ahenkli bir biçimde sürmesi amacıyla rutin işlerin sistematik ve aralıksız bir biçimde işleyişinden birincil derecede sorumlu olup; siyasi kesimin almış olduğu kararları tarafsız bir şekilde yürütür (Gökçe, Göküş ve Kutlu, 2002: 87). İdare ve siyaset ayrımını savunan Weber de ideal tip bürokrasi kavramılla bürokratların; tarafsızlık, uzmanlık, kurallara uyma ve üstlerinden gelen emirlere itaat etme, kamu politikalarının uygulayıcısı olma gibi nedenlerden dolayı politika yapım sürecinin önemli aktörleri olduğunu savunmuştur (Eryılmaz, 2013: 110; Mouzelis, 2003: 22-24).

İkinci görüş ise "idare ve siyaset ayrımının yapılamayacağı ve bürokrasinin idari ve siyasi yönünün olduğu" yönündedir. Kingley’e göre idare halkın iradesinin gerçekleşmesi amaciyla hareket eder. Halk siyasileri seçer, siyasiler de politikayı oluşturur. Bürokrasi de bu yönetişimi ve üçlü konfigürasyonu tamamlar. Bu uyum demokrasinin de gerçekleşmesi için gereklidir (Eryılmaz, 2013: 110; Demir, 2011: 67; Aksan, 2011: 2-3). Ayrıca teknik uzmanlık ve bilgisiyle politika sürecinin parçası haline gelen bürokrasinin tarafsız olamayacağından hareketle Ripley ve Franklin (1982: 40) bürokratların bir politikanın amaç ve içeriğine yönelik kişisel ve örgütsel tercihlerinin ve tutumlarının, o politikanın uygulanması üzerine önemli etkilere sahip olduğunu belirtmektedir. Şaylan'a göre ise (1986: 35) hiçbir ülke bürokrasisi Weber'in "ideal tip bürokrasi”" tarifine uymamaktadır. Zira bürokratlar siyasal sürece iki yönden dâhil olurlar. İlk olarak bürokratların siyasi eğilimleri vardır. İkinci olarak da bürokrasi içindeki örgütsel yarış ve mücadele belirli bir seviyedeki üst düzeyde (yüksek pozisyonlardaki terfi ve azillerde) siyasal nitelik almaktadır. Dolayısıyla bürokratlar apolitik sayılamaz.

Üçüncü görüş ise üst düzey bürokratların idari sistemde siyasiler karşısında bir takım özerk yetkilere haiz olması gerektiğine yöneliktir (Eryılmaz, 2013: 111). Kısmen siyaset bürokrasi ayrımını içeren bu görüşe paralel olarak özellikle 1980'li yıllardan itibaren toplumsal yaşamın şeffaf alanlarını düzenleyen ve denetleyen üst kurulların oluşturulması, teknik ve uzmanlık bilgisi gerektiren bu gibi alanlarda bürokratlara siyasiler karşısında bazı özerk alanlar bırakılmıştır.

Bürokrasinin sahip olduğu teknik, idari, hukuki bilgi ve tecrübeler ile siyaseten gelişen bazı talepler arasında çatışmaların yaşanması da kaçınılmaz bir süreç olarak karşımıza çıkmaktadır. Ayrıca tarihsel süreçte tecrübe edildiği üzere özellikle siyasal farklılıkların yoğun hissedildiği ülkelerde bürokrasinin siyasete uzak ve siyaseten tarafsız olmadığı bir gerçektir (Durgun, 2002). Bu konumlanma siyasetçilere karşı bürokratik (hantal, mevzuatçı) bakış açısının ve davranış kalıplarının yanı sıra, önemli oranda ideolojik ve kümesel saplantılardan da kaynaklanmaktadır. Bu tür kümelenmelerin ve anti demokratik ivmelenmelerin önüne geçebilmek için geleneksel denetim yolları yetersiz kaldığında ve hesap verilebilirlik ortadan kalktığında başvurulan araçlardan birisi de bürokrasinin siyasallaşmasıdır (Demir, 2011: 78).

Bürokrasinin siyasallaşması kavramı bürokrasi üzerindeki siyasi etkinin artmasını ifade etmektedir (Altunok, 2016, s.168). Merikoski (1971: 170) bürokrasinin siyasallaşmasının demokratik toplumlar da görülmesinin mümkün olduğunu, komünist-nasyonal sosyalist ve faşist gibi otoriter veya totaliter rejimlerde ise parti-devlet birliği olduğu için söz konusu olamayacağını savunmaktadır. Bu tür siyasal rejimlerde bürokrasi ve siyasi güç bütünleşmiştir (Güven, 1976: 54). Demokratik toplumlarda ise siyasal sistem içinde yürütmeye dair branş kamu yönetimidir (Eryılmaz, 1995: 30). Öyle ki, kamunun üst kademelerindeki yöneticilerin, diğer kamu kurumları ve yasama organı ile çeşitli ilişkilerle faaliyetlerin rasyonel bir şekilde yürümesinden sorumlu olmaları sebebiyle yönetim ve siyaset ayrımı doğal olarak zordur (Cem, 1976: 26). Demokratik bir zorunluluk olan bürokrasinin siyasallaşmasına yönelik kimi yazarlar tarafından çeşitli eleştiriler yapılmıştır. ${ }^{5}$ Konuyla ilgili olumsuz bakış açısına sahip Peters ve Pierre'e göre (2004:2) bürokrasinin siyasallaşması, "kamu görevlilerinin seçimi, çalışması, yükselişi, ödüllendirilmesi ve disiplini gibi konularda liyakat temelli ölçütler yerine siyasi ölçütlerin esas alınmasıdır. $\mathrm{Bu}$ durumda kamu hizmetlerinde "tarafsızlık, kariyer, adalet ve hakkaniyet ilkeleri

\footnotetext{
${ }^{5}$ Bunlar "hükümetlerce izlenilen kamu personel politikaları (Çulpan, 1980: 39); siyaseten yakınların işe alınması, yükseltmesi veya görev yerlerinin değiştirilmesi; yatırımlarla ilgili olarak plan, program ve mevzuat dışı talepler (Peker ve Aytürk, 2000: 224) olarak sıralanabilir. Bu eleştirilere iktidar değişikliklerinde gerçekleşen birçok atama kararnamesinin kamu personelinini sürekli tedirgin etmesi, personelin moral ve motivasyonunu düşürmesi de (Meriç, 1974: 75) eklenebilir.
} 
zedelenecek”, "parti menfaatlerinin önceliği sonucu yanlış yatırımlar, plansız ve temelsiz kısa soluklu kamu politikaları baş gösterecek" ve "dürüst çalışmanın engelleneceği için hızlı yöneticilik baş gösterecek ve kaliteli insan gücü israf olacaktır" (Peker ve Aytürk, 2000: 41-44; Oktay, 1983: 207-208).

Burada göz önünde bulundurulabilecek diğer bir görüş ise bürokrasi ve siyaset arasındaki ilişkinin tek taraflı olmadığı, bürokrasi siyasallaşırken siyasetin de bürokratikleşeceği yönündedir. Yönetimle siyaset arasındaki karşılıklı etkileşim ve bağımlılığı vurgulayan Pierre (1995a: 207) bürokrasinin, daha çok siyasi alanda ilerleyerek kendisi dışındaki örgütler ile network oluşturabildiğini ve çıkarlarına paralel olarak daha çok takdir yetkisi kullandığını savunmaktadır.

\section{DEVLET ÖRGÜTLENMESİ VE ISŞLEYIŞi̇ AÇISINDAN BÜROKRASINIIN KONUMU}

Devlet örgütlenmesi ve işleyişinde siyasal içerikli değişkenlerden kaynaklı olarak çeşitli bürokrasi biçimleri görülebilir. Siyasal sistemin özellikleri ile kamu bürokrasisine hâkim olan siyasi yaklaşımlar yakından ilişkilidir. Diğer bir ifade ile siyasal sistemin değişkenleri kamu bürokrasilerinin örgütlenme ve etkinlik biçimlerini belirler (Heper, Kim ve Pai,1981: 127). Bürokrasiyi yapı, işleyiş ve sistem içerisindeki konum açısından etkileyen bu değişkenler, aynı zamanda siyaset ve bürokrasi ilişkisinin ana çizgilerini belirleyerek kamu yöneticiliğinin profesyonelleşme süreçlerini de etkilemektedir (Karasu, 2001: 211).

Ülkelerdeki bürokrasi görünümleri toplumdaki gücünün seviyeleri temel alındığında (ülkelere göre değişiklik göstererek) egemen, güçlü, yarı-güçlü, güçsüz olarak sınıflandırılabilir (Riggs, 1997: 2). Örneğin tarihsel süreçte merkeziyetçi yapıdaki Prusya'da egemen bürokrasi bulunmaktayken, merkeziyetçi ama güçlü parlamenter gelenek nedeniyle otokritik olmayan devlet yapısındaki Fransa'da egemen olmayan ancak güçlü bürokrasi bulunmaktadır. Yine güçlü parlamenter geleneğe haiz İngiltere'de yasama ve yürütmenin sıkı şekilde denetlediği yarı güçlü bürokrasi bulunurken, federal yapıdaki ABD başkanlık sisteminde ise başkanın yönetim aygıtı olan güçsüz bürokrasi bulunmaktadır (Karasu, 2001: 212).

Bürokrasinin bu görünümleri tarihsel süreçte kendini göstermiştir. Örneğin Şaylan'a göre (1976: 39) İngiltere'de parlamenter sistemde (yumuşak güçler ayrılığı gereği) bürokrasinin parlamento tarafindan etkili biçimde denetlenmesi, kariyer bürokrasisinin ve pek çok denetleyici düzeneğin oluşturulmuş olması bürokrasinin güçlü-egemen konuma gelmesini önlemiştir. Khator’a göre ise (1997: 75) parlamenter sistemlerde başkanlık sistemine göre bürokrasi daha güçlüdür. Zira ABD'de devlet yönetiminde bürokrasinin güçlenmemesi için, 7. ABD Başkanı Andrew Jackson döneminde (1829) her gelen iktidarın kendi bürokratlarını seçebilmeleri ilkesi olarak da ifade edilebilen yağma (spoil) sistemi kurumsallaştırılarak bürokrasinin süreklilik göstermesi niteliği zayıflatılmıştır. Kayırmacılığın ortadan kaldırılması için 1883'te çıkartılan Pendleton Kanunu ile meritokrasiye $^{6}$ geçilse de bu konuda eski alışkanlıkların tamamen sona erdiğini söylemek mümkün değildir (Tataroğlu, 2006). ABD'de bürokrasi makamları geçici ve sürekli nitelikte olup, türdeş bir bürokrasi yoktur. Bu durum da kariyer bürokrasisin birliktelik duygusunu oluşumunu engellemekte ve geçici-sürekli bürokratlar gerilimi yaşatmaktadır. Riggs'e göre (1997: 21) bu niteliğiyle ABD bürokrasisi "küçük, heterojen, güçsüz ancak profesyonel" niteliktedir. Almanya'da bürokrasinin tarihsel süreçteki güçlü konumu, bürokrasinin uzman memurlardan oluşması, bürokrasideki kamu yöneticilerinin aynı zamanda kabinede de yer alması, parlamentonun bürokrasiyi kanuni düzenlemeler sebebiyle yeterince denetleyememesi gibi faktörlerden dolay1 yasama organı bürokrasiye göre geri planda kalmıştır (bkz. Karasu, 2001: 213). Bürokrasinin bu egemen yapısı aynı zamanda tek parti iktidarının olduğu ülkelerde görülmekte, siyasal iktidar ve devlet yönetimi büyük ölçüde özdeşleşmektedir. Bu durumda parti yönetimi ile üst düzey bürokrasiyi ayırmak zorlaşmaktadır (Riggs, 1997: 23-24). Bu noktada Çin ve dağılan Sovyetler Birliği gibi tek parti rejimi ile yönetilen ülkelerde egemen bürokrasi (Hirszowiez, 1980), benzer ş̧ekilde Türkiye'de 1923-50 arası dönemde ise yer yer güçlü ve egemen bürokrasi olduğunu söylemek mümkündür (Karasu, 2001).

\section{HÜKÜMET SISTEMLERİ AÇISINDAN BÜROKRASINIIN KONUMU}

Bürokrasinin konumuna hükümet sistemlerinin uygulamaları perspektifinden bakıldığında ise yapı ve işleyiş olarak bürokrasi çeşitli değişkenlikler göstermektedir. Örneğin olağanüstü şartlarda tecrübe edilen ve geçici bir yönetim biçimi olan meclis hükümeti sisteminde idare, parlamento içinden seçilen bakanlar ve onlara bağl1 çalışan kamu görevlilerinden müteşekkildir. Bu sistemde bürokrasi siyasal tercihlerde bulunmaz ve siyasal kadroların emrindedir (Kutlu ve Kahraman, 2017: 4).

\footnotetext{
${ }^{6}$ Meritokrasi; toplumsal kaynaklarla ilgili tasarruflarda toplumsal statülerin değil belirlenmiş kriterlerin esas alınmasıdır (Torun, 2009: 89).
} 
Parlamenter sistemlerde ise yasama organı hem yürütme hem de diğer icracı birimler üzerinde etkin olması gereklidir. Parlamento tarafından çıkartılan kanunların ve ortaya konulan politikaların uygulanmasında hükümet siyasi ve icrai yönden sorumludur. Bununla birlikte genelde parlamentonun bürokrasiye nüfuz etme kabiliyetinin düşüklüğü sebebiyle bu etkinlik hükümetten bürokrasiye yönelik olarak gerçekleşmiştir (Altunok, 2016: 173). Hükümetin siyasi atamaları ise başkanlık sistemlerindeki kadar olmamakla birlikte parlamenter sistemde de görülmekte; pek çok kariyer sistemi uzantılı bürokratik makama çeşitli yöntemlerle siyaseten atamalar yapılmaktadır (Tataroğlu, 2016: 99-100; Özer ve Özmen, 2017: 22). Ancak parlamenter sistemlerde bu tür yöntemlerin kullanımı çok dar ve sınırlı olduğu için siyaseten patronaj ilişkileri genelde hâkim değildir. Hükümetler çok uzun yıllar iktidarda kalmadığg sürece siyaset doğrudan bürokrasiye etki etmez ve onu denetim altına alamaz. Ancak uzun süreli iktidar dönemlerinde siyasal nitelikteki bürokratik makamlarda yer bulan bürokratlar, kendilerine yakın gördükleri memurları yetiştirebilir ve süzebilir, bürokratik egemenlik elde edebilir (Tataroğlu,2016: 99-100). Bu gelişmelere dair süreler liyakat sistemine dayalı personel rejimi olan ve parlamenter sistemle yönetilen ülkelerde, personel sistemlerine bağlı olarak değişebilmektedir. Bununla birlikte Emre (1996: 74-75) parlamenter sistemde bürokrasinin, başkanlık sisteminin aksine siyasetin baskıları karşısında daha korunaklı olduğunu savunmaktadır. Örneğin parlamenter sistemin beşiği İngiltere'de üst düzey kamu yöneticilerinin hükümet ile ilişkileri keskin kurallarla belirlenmiş olup, atanmaları tamamen yansızlık ve yalıtılmışlık esaslı gerçekleşmektedir. Böylece siyasetçilerin bürokratlar üzerinde keyfi müdahalesinin yanı sıra bürokratların da siyasetçileri engelleyen tutum içinde olmaları önlenmekte ve kamu yönetimi "apolitik bir kariyer servisi" olarak kabul edilmektedir. $\mathrm{Bu}$ anlamda parlamenter sistemin uygulandığı ülkelerin bürokrasilerinde yükselme ölçüt ve süreçlerinde katiyet olmamakla birlikte bir otomatiklik söz konusu olup memurlar belirli bir süreçte nereye ne kadar zamanda yükselebileceğini tahmin edebilmektedir (Çevikbaş, 1992:163). Ayrıca Kutlu'ya göre (bkz. Kutlu ve Kahraman, 2017: 5) İngiltere'deki parlamenter sistemde kamu görevlileri (bürokrasi) tam tarafsızlık ilkesi doğrultusunda yürütme organıyla aynı hareket ederler ve siyasi amirlerinin politikalarına ayak uydurarak, kendi tercihlerini hayata geçirmek için çaba sarf etmezler.

Yarı başkanlık sisteminin çıkış yeri olan Fransa'da ise üst düzey kamu yöneticileri sürekli, tarafsız, uzman bir statü içinde olup, siyasal iktidarın müdahalelerine karşı özerk bir alana sahiptir. Geçici bir yönetici olarak bakanın maiyetinde yerleşik, sürekli, kalıcı bir yönetici kadro bulunmaktadır. Bu doğrultuda kamu yönetiminin (üst düzey yöneticiler ve çalışmaların) siyasallaşmasını önlemek ve bakanlara uzmanlık bilgisi sağlamak için bakanlık kabinesi tesis olmuştur. Bakanlara danışmanlık hizmeti sağlayan bakanlık kabinesi, çalışma arkadaşları, dostları ve güven duyduğu kişilerden bakanın takdiriyle belirlenen belli sayıda kişiden oluşacak şekilde tasarlanmıştır (Gournay\& Kesler \& Siwek-Pouydeseau, 1967). Siyasal bir organ olmayan kabinenin hiçbir sorumluluğu da yoktur ve tüm sorumluluk bakana aittir. Bakanlık kabinesi, bakanın siyasal güç ve yetkesinden yararlanarak bakanı temsilen ve onun adına bürokrasiyi yönetir ve denetler. İdari ve siyasi açıdan merkezi yönetimin siyasi beyni konumundaki bakanlık kabinesi, bakan ile bürokrasi arasında köprü vazifesi görmektedir (Oytan, 1984: 52-62). Ancak kabinelerin, kamu yönetimi içinde giderek ayrı bir güç alanına evirilmesi ve kamu yöneticileri için idari hiyerarşide çabuk yükselme basamağına dönüşmesi de mümkündür (Pierre, 1995: 49). ${ }^{7}$

ABD'deki başkanlık sisteminde ise tüm üst düzey federal kamu görevlilerinin üzerinde hem Başkanın hem de Kongrenin etkinliği bulunmaktadır. ${ }^{8} \mathrm{Bu}$ etkinlik bürokrasinin konumunu ve siyasetle arasındaki ilişkileri de belirlemektedir. Bu üst düzey kamu görevlileri Başkan ile (önemli sayıda atama Senato onayıyla) gelirler ve giderler. ${ }^{9}$ Sistem üzerinde etkisi oldukça belirleyici olan Başkanların kişiliklerinin güçlü ya da zayıf olmasının da Amerikan kamu yönetimi ve bürokrasi üzerinde değişkenlik gösteren etkileri olmuştur. ${ }^{10}$ Diğer bir ifadeyle güçlü Başkanlar gücü dizayn ederek güçlü etkiler bırakmış, ${ }^{11}$ kuşatan bürokratik kişi ve kurumlardan

\footnotetext{
${ }^{7}$ Bürokrasinin siyasal sistemdeki konumu ülkelerin siyasal kültürleriyle de ilgilidir. Örneğin İngiltere'nin aksine Fransa'daki kamu görevlileri siyasal parti faaliyetlerine katılabilmektedirler. Başkanlık sisteminde ise üst düzey kamu görevlileri doğrudan siyasal sistemin parçası olup siyasetle iç içe örgütlenmişlerdir.

${ }^{8}$ Kongre bürokrasi üç açıdan denetler. Birincisi Kongre bürokrasiyi kendine bağlı bir organ, kendisini de işin sahibi olarak (asil vekil) görür. İkincisi bürokrasinin yanlış yaptığı işleri düzeltme hakkı vardır. Üçüncü olarak da bürokrasinin yetki ve sorumlulukları yasama faaliyetiyle belirlenir (Tataroğlu, 2006: 105-106). Bu açıdan bürokrasinin Başkan ve Kongre tarafindan denetim ve kontrolü söz konusudur.

${ }^{9}$ ABD'de yürütmede 9 bin üst düzey kamu görevlisi bulunmakta, Başkan tüm branşlarda 4 binden fazla üst düzey kamu görevlisi atamaktadır. Bu atamaların 1200'den fazlası Senato onayına tabidir. (Heady, 1988: 410; Diehm, 2017). Bu kamu görevlileri Başkanın partisinden olmak zorunda değildir (Kutlu ve Kahraman, 2017: 1-26).

${ }_{10}$ Örneğin Wilson'ın 1880'lerdeki yönetimi “kongre hükümeti”, 1960'lardaki Nixon ve Johnson yönetimleri ise "emperyal başkanllk" olarak ifade edilmiştir (Heady, 1988: 398-399).

${ }^{11}$ 1933'e kadarki ABD başkanlarının (Lincoln hariç) zayıf ve silik kişilikli profilleri Roosvelt dönemiyle birlikte değişmiş ve kurumsallaşma süreçleri de başlamıştır. Örneğin Wilson döneminde Başkanın yalnızca 3 yardımcısı varken 1939’te “Başkanlık Yürütme Ofisi” kurulmuştur.
} 
korunabilmiştir. Zayıf Başkanlar ise bunu başaramamış ve bürokrasi etkisinde kalmıştır. ${ }^{12}$ Kongrenin Başkana karşı sıkı kontrol kurması halindeyse Başkanın bürokrasi üzerindeki etkinliği önemli derecede zedelenebilmekte ve bu durumda bürokratların bir kısmı Kongreye itaat etmek isteyebilmektedir (Ball \& Peter, 2007: 179). Şayet güçler ayrımından kaynaklanan siyasal bir bölünme yaşanırsa Başkanın bürokrasiyi sınırlama kapasitesi de azalır ve bu tür sistemler uzun dönem bürokrasi üzerinde kontrol sorunu yaşar. Büyük krizlerde ise Başkanlar veyahut bürokratlar yönetimi ele alırlar. Başkancı bürokratik otokrasiler ise oldukça kırılgan olup yıkılma eğilimlidirler. Bununla birlikte Riggs'e göre (1994: 99) çoğu parlamenter sistem bu tür durumlara daha dirençli olup güçlü bürokrasi daha iyi kontrol edilebilir ve kamu yönetimin etkinliği ve rejimin devamlılığı sağlanabilir. ${ }^{13}$

ABD'de başkanlık sisteminde kamu görevlileri Başkanın yanı sıra bütçe sürecindeki etkisinden dolayı Kongreye karşı da sorumludur. ${ }^{14}$ Ayrıca Başkan Senatonun onayı gerektiği için kamu görevlilerini de bu profile uygun seçer. Halkın aracı gibi olan bürokratlar son derece hassas durumdadırlar (Burke, 1988: 11). Politikaların yapılması ve uygulanmasında ise bürokratların takdir yetkisi bulunmamakta olup yapacakları işler kanunla düzenlenmiştir.

Başkanlar bu dengede bürokrasiyi kontrol edebilmenin yanı sıra Kongre ile ilişkiler açısından da patronaj atamalarına ihtiyaç duyarlar. Zira başkanlar talep ettikleri kanunu çıkartabilmek için Kongre üyelerinin desteğine ihtiyaç duyar ve Kongredeki vekillerini parti disiplini içinde tutmaya çalışırlar. Vekiller de Başkandan bazı atama taleplerinde bulunabilmektedirler (Riggs, 1994: 100). Ancak bu atamalarda da atanacaklar mutlaka işin gerekleri ile bürokratların nitelikleri uyumlu olmak ve teknik bilgiye haiz olmak zorundadırlar. Aksi halde kamu yönetiminde çürümeler yaşanacaktır (bkz. Riggs, 1994: 101).

Başkanlık sistemiyle uyumlu bir yapı olan federalizmin de bürokratik yapı üzerine önemli etkileri bulunmaktadır. Zira federalizm bir partinin tüm ülke üzerinde egemenlik kurmasını engeller ve merkezi bürokrasiyi zayıflatır. Daha geniş bir ifade ile bürokrasi çok sayıda coğrafi ve otonom devlete bölünmüş olduğu için merkezi bürokrasinin ölçeği de küçülür, kamu görevlisi sayısı ve güç potansiyeli azalır. Ancak bu durumda ise coğrafi bölünmenin olmadığı askeri bürokrasinin merkezi bürokraside güç potansiyeli artar. Federal sistemdeki ülkelerde askeri yoğunlaşmanın merkezde olması ise darbe açısında kolaylaştırıcı etkiye sahiptir (Riggs, 1994: 110). İktidarın yatay ve dikey olarak bölünmesi eyaletler ve yerel yönetimler üzerinde Washington'un etkisini ve dolayısıyla da Başkanın etkisini önemli ölçüde azaltır (Çitçi, 1997: 24). Kamu görevlilerinin çoğunluğunun ise eyaletler ve yerel yönetimlerde çalışması nedeniyle ABD bürokrasisi parçal1, temsili ve açık elit durumdadır (Heady, 1988: 409). ${ }^{15}$ Ayrıca ABD'de merkezi bürokrasi birçok üniter devlete oranla daha azdır. ${ }^{16}$

\section{5. ÜST DÜZEY YÖNETICILERIN ATANMASI}

Siyasal sistem fark etmeksizin tüm ülkelerde iktidarda bulunanlar politika ve kararlarını uygulamaları için üst düzey yöneticileri kendileri belirlemek isterler (bkz. Güran, 1980: 106; Onaran, 1967: 6; Weber, 1993: 82). Örneğin birçok parlamenter sistemde bile göreve gelen her bakan, bürokrasideki üst düzey kadroyla (bir müddet de olsa) çalışmaya devam etmek durumunda olmakla birlikte, pratikte siyasal ve stratejik kararlarda etkin konumdakiler için, siyaseten kendisine ve partisine yakın düşünce ve görüşlerdeki kişileri getirme eğilimi gösterirler (Ardanıç ve Ergun, 1980: 4). Uygulamadaki üst düzey yönetici atamalarında ise kamusal politikalardaki roller bakımından üç model mevcuttur (Halligan, 2011: 65):

- Tarafsız atamalara dayanan model (Liyakat sistemi, İngiltere görülebilir.)

- Siyasal kontrole dayanan model (Belli şartlara bakılarak doğrudan atama, ABD’de görülebilir.)

\footnotetext{
12 Örneğin Kennedy kendini korumak için sürekli olarak teşkilatta değişiklik yapmıştır. Eishenhover'ın ise etrafındaki bürokratlar işleri ayrıntılı olarak düzenlemiş ve planlamıştır. Duverger'e göre (1986: 93) bu durum Başkanın değil yalnızca etrafındaki bürokrasinin iktidarını desteklemiştir.

${ }^{13}$ Pek çok başkanlık sistemindeyse rejim güçlü bürokrasi tarafından ele geçirilmiş olup bunun yegane istisnası ABD'dir. İç savaş ve derin kriz dönemlerinde başkanlar anayasal sınırların dışına çıkmışlarsa da anayasayı askıya almamış veyahut Kongreyi dağıtmamışlardır. Bu durumun sebebi Riggs'e göre; "partizan olmayan profesyonel kariyer sistemi”, "partizan politik atamaların devam etmesi ve partizan olmayan danışmanlık sistemi”, "federalizm” ve "kamu bürokrasisinin bazı yapılması gereken işlerinin özel sektörce yürütülmesi”dir (Riggs, 1994: 98; Uçman, 2014: 102).

${ }^{14}$ Parlamenter sistemlerdeki emret bakanım sözünün yerini emret vekilim almıştır. ABD başkanları ve bakanlar bu nedenle bürokratların Kongre üyeleriyle yakın olmalarını istememektedirler (Eryılmaz, 2010: 118; Tataroğlu, 2006: 105).

${ }^{15} 275.562 .673$ olan nüfusun 2.777 .000 'i merkezi idarede, 4.746 .000 'i eyaletlerde ve 13.049 .000 'i belediye ve diğer yerel kuruluşlarda olmak üzere toplamda 20.572.000 kamu personeli istihdam ediliyor (OECD, 2000 verileri).

${ }^{16}$ Zira eğitim hizmetleri gibi birçok alan özel sektör tarafından yerine getirilmektedir (örneğin eğitim bakanlığı personeli 6 bindir) (Heady, 1988: 403). Ancak merkezi kamu hizmetlerinin büyük oranda kamu görevlileri tarafından görüldüğü diğer başkanlık rejimlerinde merkezi bürokrasi ABD’ye göre daha çoktur (Eryılmaz, 2010: 120; Uçman, 2014: 102).
} 
- Parti üyeliğine dayanan model (Sadakat esaslıdır. Az gelişmiş ve gelişmekte olan ülkelerde görülür. Bazı gelişmiş ülkelerde de görülebilir.)

Bir diğer tasnife göre üst düzey yöneticilerin atanmasında (terfi, değerlendirme, kurum değiştirme dâhil) siyasal esaslı atamalar (politikaları uygulayacağına inanılan yakın kişilerin atanması) ve liyakat esaslı atamalar (görevin gerekliliklerine en uygun ve yeterliliklerine inanılanların kariyer kadrolarına atanması) iki ana yöntem olarak sayılabilir (Ergun, 2004: 297). Liyakat esaslı atamalar kayırmacılık veya kişisellik yerine yeterlilik ve ehliyet ilkelerine dayanır (Denhardt \& Denhardt, 2009: 286). Personel seçimindeki kıstas bürokraside tanımlanan pozisyonlar için eğitim, uzmanlık, genel olarak yetkinlik ve entelektüel beceriye haiz olmaktır (Peters, 2010: 84). Bununla birlikte liyakat esaslı atamalar idari, siyasi ve toplumsal sorunlara da yol açabilmektedir. Ayrıca sistemin amaçları doğrultusunda tarafsız yönetici kadronun oluşturduğu politika, siyasal iktidar değişikliklerinde terk edildiğinde üst düzey kamu yöneticilerinin motivasyonu düşecektir. Gene üst düzey kamu yöneticilerinin değişen siyasal iktidarlar karşısında tarafsız, eşit ve bağl1lıkla hizmet üretmesi gerçekte mümkün değildir (Meriç, 1974: 74).

Liyakat esaslı atama ile kamu politikalarını yöneten değerlerden bağımsız mekanik bir yönetici belirleneceği; böylelikle kanuni ve teknik kıstasların tercihleri yönlendireceği öngörülmektedir. Siyasal esaslı atamayla seçilen yöneticiler de ise liyakat esaslı atmalara göre siyasal liderin politikalarına bağlılık daha fazladır. Ancak bürokrasideki siyasal atamalarda siyasal eğilimin yanı sıra yönetme kabiliyeti de dikkate alınmalıdır (Peters, 2010: 83). Siyasal partiler iktidara gelmeleriyle birlikte politika ve vaatlerini yerine getirebilmek için doğal olarak kendi yönetimlerini kurmak isteyeceklerdir. Dolayısıyla bu yönde gerçekleştirecekleri atamalarda liyakat ve ehliyetin yanı sıra güven ve sadakat (Tutum, 1976: 13) kıstaslarıyla da yönetim kadrolarını oluşturacaklardır. Tüm ülkelerdeki üst düzey kamu personel yönetimi uygulama örnekleri göz önünde bulundurulduğunda salt siyasal nitelikli veya salt liyakate dayalı atama usulü görülmemektedir. Ancak ülkelerdeki politik kültür, personel yönetim sistemi, kamu yönetimi geleneği ve hukuki düzen siyasal nitelikli atama oranlarını etkilemektedir.

Liyakatin gözetildiği üst düzey kamu yöneticiliği kariyere ve pozisyona dayalı olabilmektedir. Kariyer esaslı üst düzey kamu hizmetine atanma, kamuya yeni girecek üniversite mezunu adayların katılacağ 1 rekabetçi sınavların ardından gerçekleşmektedir. ${ }^{17}$ Dışa kapalı bir yapıdaki bu sistemde, ortak üst düzey kamu hizmeti, değerler sistemi ve diğer kurumlardaki üst düzey yöneticilerle iyi bir iletişim (veya network) meydana gelir. Ancak memuriyet güvencesine dayanan kariyer sisteminde kurum içinden yüksek performans gösterenlerin veya dışarıdan geleceklerin önünü kapatma gibi olumsuz durumlar da söz konusudur (World Bank, t.y: 2). Bu dışa kapalı yap1 kişileri toplumsal hayattan uzaklaştırmakta ve toplumsal kesimler sosyo-ekonomik ve kültürel farklılıklar nedeniyle kamuda üst düzeyde temsil edilememektedir (Şengül, 2009: 298). Pozisyon esaslı üst düzey kamu hizmetinde; ${ }^{18}$ profesyonel olarak yeterli, tecrübeli ve idarecilik yeteneklerini haiz kişiler siyasal tercihle atanır. Bu kadrolara diğer kamu kurum ve kuruluşlarından ve özel kesimden de geçişler mümkün olup bu durum dışarıdan kurumsal kültüre ve dinamizme katkı sağlayabilmektedir. Bu durumun tersinin de görülmesi mümkün olup, sistem patronaja dayalı atamalara da evirilebilir ve ortak yönetim kültürünün gelişimini baltalayabilir. ${ }^{19}$ Kariyer esaslı sistem başlangıçta yapılan giriş sınavındakilerin az bir kısmının üst kademe kadrolara atanabildiği (yükselebildiği) rekabet yoğun bir sistemdir. Pozisyon esaslı sistemde ise personelin seçimi belirli ölçütlere dayanan bir sürecin ardından kademeli olarak yapılabilir (Word Bank, t.y: 3-5).

Başkanlık sisteminin uygulandığı ABD'de kamu görevlileri liyakat ilkesinin uygulandığı ve siyasetin rolünün bulunmadığı "sınıflandırılmış veya sürekli görevliler" ve başkana yardımcı olan ve başkan tarafından atanan "sınıflandırma dışı tutulan istisnai görevliler" olarak ikiye ayrılabilir. Tarihsel süreçte edinilen tecrübeler sonucunda (yağma/spoil sisteminden liyakat/merit sistemine geçilmiştir) üst kademelere siyasal atama yapılırken, alt kademelere ise yeterlik esaslı kariyer sistemiyle işe alma gerçekleşmektedir (Cigler,1990: 638). Başkan seçilmesinin ardından anayasada kendisine verilen yetki ile önceden belirlenmiş yöneticilik statüsüne atama gerçekleştirir (Peters, 2010: 84). Bu atamaların önemli bir kısmı (4 bin atamadan bin 200'den fazlası) Senatonun onayına sunulur (Diehm, 2017). Bu sistemde halkın seçimiyle yürütmenin başına geçen Başkana politikalarını uygulayabilmesi için ekibiyle çalışabilme imkânı tanınabilmesini hedeflenmiştir. Seçilmiş

\footnotetext{
${ }^{17}$ Örneğin Fransa, Hindistan, İngiltere, İspanya, Japonya, G. Kore ve Malezya gibi ülkelerde uygulanır.

${ }^{18} \mathrm{ABD}$, Avustralya, Belçika ve Hollanda gibi ülkelerde uygulanır.

${ }^{19}$ ABD dişında bütün başkanlık sistemlerinde bürokratlar uzun süre görevde kalacak şekilde istihdam edilmiştir. Parlamenter sistemlerde ise patronaj sistemi elemine edilmiş ve kariyer bürokrasisi oluşturulmuştur. Bunun oluşturulmasında siyasilerin desteği ve parlamenter sistemlerin büyük katkısı olmuştur. Zira parlamenter sistemleri güçlü bürokrasileri denetleyebilme kapasitesine sahiptir. Başkanlık rejimlerinde ise memurların direnci ve başkanların patronaj bürokrasisini kaldırmak istememeleri nedeniyle bu dönüşüm gerçekleşmemiştir. Zira Başkanlar Kongre karşısında kendilerini güçlü tutmak istemişlerdir (Riggs, 1994: 100).
} 
siyasetçileri engellememesi için bürokrasinin etki alanının daraltıldığı bu yönetim sisteminde, üst düzey atamalarda siyasetçilere daha geniş takdir yetkisi tanınmıştır. Bununla birlikte bu siyasal atamalar siyasal bağlılık esasının yanı sıra, görevlerin gerektirdiği liyakat koşulu da aranmaktadır (Emre, 1996: 81). Bürokratların görevde yükselme ve hizmetten çıkarılma esaslarını belirleyen Liyakat Koruma Kurulu (Merit Protection Board) Başkan ve Senatoya çeşitli rapor ve görüşler sunmaktadır. ${ }^{20}$ Parlamenter sistemle yönetilen ve personel rejiminde kariyer ve pozisyon esaslı uygulamaların olduğu İngiltere'de ise 4 binden fazla üst düzey kamu görevlisinin 200 kadarı siyasal atamaya konu olmaktadır (Aslan vd., 2016: 161-162). Yarı başkanlık sistemiyle yönetilen ve kamu personel rejiminde liyakat sisteminin geçerli olduğu Fransa'da ise siyasal atama usulü 1848 'deki anayasa değişikliklerinden itibaren sadece valilik ve müsteşarlık gibi kadrolarda görülmekte; genel olarak liyakat ilkesi esas alınmaktadır. Fransa'da 5 bin civarı üst kademe yöneticisi bulunmakta iken bunun dört yüzü siyasal atamayla göreve gelir (Heady, 1988: 410). Ayrıca Fransız Ulusal Kamu Yönetimi Okulu (ENA) mezunu olmak sistemde üst yönetici atanmanın temel şartlarındandır.

\section{SONUÇ}

Bürokrasinin siyasal açıdan tarafsız olup olmadığı veyahut olması gerekip gerekmediği modern yönetim bilimin cevabını aradığı soruların başında gelmektedir. Bu konuda demokratik çerçevede kalınması gerektiği konusunda her ne kadar hem fikir olunsa bile bu bürokrasiye yüklenen roller ve bakış açıları tarihsel süreçte değişikliğe uğramış; tarafsızlık, taraflılık ve özerk alan ekseninde çeşitli görüşler savunulmuştur. Bununla birlikte demokrasinin olmazsa olmaz gereği olan seçilmişlerin öncülüğ̈̈ veyahut üstünlüğünün gereği olan bürokrasinin taliliği hususunun nasıl sağlanacağı, iş başına gelen seçilmişlerin nasıl politikalarını uygulayacağı ve hedeflerine ulaşacağı açısından tartışmalar devam etmiştir. Yine aynı şekilde gerek seçilmişlerin gerekse bürokrasinin ne tür hareket tarzı ve beklentiler içinde olduğu da çeşitli görüşlerce değerlendirilmiştir. Esasen bu konuda hem fikir olunan mutlak doğruların olunamayacağı, tüm değerlendirmelerin göreceli olduğu ise aşikârdır.

Yine ülkelerin demokratik seviyeleri açısından bürokrasi ve siyaset ilişkileri ele alındığında, bürokrasinin ülke tarihi ve devlet yapısında üstlendiği rol ve sistem içerisindeki gücüne göre oluşan dengeler de bürokrasi ve siyaset arasındaki ilişkileri belirleyen bir unsur olarak karşımıza çıkmaktadır. Bu dengeler yine her ülkenin kendi hükümet sistemlerindeki gelişmeleri etkileyebilmekte veyahut bu gelişmelerden etkilenebilmektedir.

\section{KAYNAKÇA}

AKSAN, Gamze vd, (2001), “Gerilim ve Uzlaşma: Demokrasi Ekseninde Bürokrasi ve Siyaset İlişkisi Üzerine Bir Değerlendirme”, SÜ SBE Dergisi, S. 25.

ALTUNOK, Hatice (2016), “Atama Yetkisi ve Bürokrasi Siyaset İlişkisi Üzerine Bir Değerlendirme”, Mehmet Akif Ersoy Üniversitesi SBE Dergisi. 8(14).

ARDANIÇ, Bülent ve ERGUN, Turgay (1980), “Siyasal Nitelikli Yüksek Yönetici Atamaları”, AIID, 13(2).

Aslan, Onur Ender vd. (2016), Merkezi Personel Hizmetleri Örgütlenmesi, TODAİE.

BALL, Alan \& PETER, Guy (2007), Çağdaş Siyaset ve Yönetim, 1. Baskı, Yayın Odası.

BURKE, John P. (1988), Bureaucratic Responsibility. London, The John Hopkins University Press.

CEM, Cemil (1976), Türk Kamu Kesiminde Üst Düzey Yöneticiler, TODAİE, Ankara, Sevinç Matbaası.

CIGLER, Beverly A. (1990), "Public Administration and the Paradox of Professionalization", Public Administration Review, 50(6).

ÇEVIKKBAŞ, Rafet (1992), "Batılı Ülkelerde Kamu Yönetiminin işleyişi ve Siyasal İktidarla Olan İlişkisi”, TíD, S. 364

ÇİTÇI, Oya (1997), “Başkanlı Sistemi Çözüm mü?”, AİD, 30 (4), TODAİE Yay.

DENHARDT, Robert B. \& DENHARDT, Janet Vinzant (2009), Public Administration: An Action Orientation,. California, Thomson Wadsworth.

DEMIR, Fatih (2011). Bürokrasi - Siyaset İlişkisi ve Bürokratların Seçilmişlerce Kontrolü Sorunu, Yönetim ve Ekonomi Dergisi, 18(2).

\footnotetext{
${ }^{20}$ ABD 1920'lerde liyakat sistemine geçmekle birlikte üst yöneticilerin \%0,2'i partizan atamalara tabidir (Uçman, 2014: 96).
} 
DIEHM, Jan et al. (2017), Tracking Trump's nominations. CNN. https://edition.cnn.com/interactive/2017/politics/trump-nominations (Erișim Tarihi: 01.01.2020)

DURGUN, Şenol (2002), Türk Kamu Yönetiminde Bürokratik Siyaset, Gazi Üniversitesi İi̇BF Özel Sayısı.

DUVERGER, Maurice (1986), Seçimle Gelen Krallar, Necati Erkurt (çev.), 2. Bask1, İstanbul, Kelebek Yay.

EMRE, Cahit (2003), Yönetim Bilimi Yazıları, Ankara, İmaj Yay.

EMRE, Cahit (1996), "Bürokrasi - Siyaset Perspektifinde Yayginlaşan Yolsuzluklar”, Kamu Görevlileri ve Siyasal Haklar Sempozyumu, Ankara, TMMOB.

ERYILMAZ, Bilal (1995), Kamu Yönetimi, İzmir, Akademi Yay.

ERYILMAZ, Bilal (2010), Kamu Yönetimi, 3. Bask1, Ankara, Okutman Yay.

ERYILMAZ, Bilal (2013), Bürokrasi ve Siyaset: Bürokratik Devletten Etkin Yönetime, 5. Bask1, İstanbul, Alfa Yay.

FARAZMAND, Ali (ed.), (1997). Modern Systems of Government: Exploring the Role of Bureaucrats and Politicians, California, Sage.

GEERTH, Hans \& Mills, C. Wright (eds.) (1977), From Max Weber Essays in Sociology, London, Routledge \& Kegan Paul.

GOODNOW, Frank J. (1900), Politics and Administration.

GOURNAY, Bernard, KESLER, Jean François \& Siwek-Pouydeseau, Jeanne (1967), Administration Publique, Paris, Presses Universitaires de France.

GÖKÇE, Orhan, GÖKÜŞ, Mehmet ve KUTLU, Önder (2002), Kamu Yönetimi Ders Notları, Konya.

GÜRAN, Sait (1980), Memur Hukukunda Kayırma ve Liyakat Sistemleri, İstanbul, İ̈̈ Yay.

GÜVEN, H. Sami (1976), “İdare Siyaset İlişkileri ve Personel Yönetimi Açısından Önemi”, AID, 6(1).

HALLIGAN, John (2011), "Leadership and the Senior Service from A Comparataive Perspective”, B. Guy Peters ve Jon Pierre (ed.), The Handbook of Public Administration, California, Sage.

HEADY, Ferrel (1988), "The United States". Donald C. Rowat (ed.), Public Administration in Developed Democracies: A Comperative Study, NY, Marcel Dekker Inc.

HEPER, Metin, KİM, Lim Chong ve PAI, Tong. Seong (1981), Siyasal Rejimler ve Kamu Bürokrasisi, Türk ve Güney Kore Yüksek Kademe Yöneticileri İle İlgili Karşılaştırmalı Bir Inceleme. Ahmet Şükrü Esmer'e Armağan, Ankara, AÜSBF Yay, (468).

HIRSZOWIEZ, Maria (1980), The Bureaucratic Leviathan: A Study in the Sociology o f Communism, Oxford, Martin Robertson.

KARASU, Koray (2001), Profesyonelleşme Olgusu ve Kamu Yönetimi, Ankara, Mülkiyeliler Birliği Vakfi Yay, Tezler Dizisi.

KAYA, Yahya Kemal (1994), Çağdaşlaşma Yolunda Deve Dikenleri, Ankara, Bilim Yay.

KHATOR, Renu (1997), "Professionalizm in Bureaucracy: Some Comparisons Based on the Indian Case”, Ali Farazmand (ed.). Modern Systems of Government: Exploring the Role of Bureaucrats and Politicians, California: Sage.

KUTLU, Önder ve KAHRAMAN, Selçuk (2017), "Türk Cumhurbaşkanlı̆̆ı Sisteminin Kamu Yönetimi Açısından Değerlendirilmesi” Ferhat Uslu (ed.), Türk Anayasa Hukukunun Güncel Sorunları, Sakarya, Beşköprü Yay.

LAPALOMBARA, Josephe (ed.) (1967), "An Overview of Bureaucracy and Political development and Political development”, Bureaucracy and Political Development, NJ, Priceton University Press.

MERIÇ, Osman (1974), "Siyasal İktidar ve Yüksek Yöneticiler Sorunu”, AID, 7(3-4).

MERIKOSKI, Veli (1971), "İdarenin Siyasileşmesi”, C. Tutum (çev.), AİD, TODAİE, C.4. 
NISKANEN, William A. (1971), Bureaucracy and Representative Government, Chicago, NY, Aldine/Atherton.

OECD, 2000 Verileri, http://arsiv.ntv.com.tr/news/118304.asp (Erișim Tarihi: 11 Mayıs 2020)

OKTAY, Cemil (1983), Yükselen İstemler Karşısında Türk Siyasal Sistemi ve Kamu Bürokrasisi, İstanbul, İ.Ü. Yay.

ONARAN, Oğuz (1967), Yönetici Sınıfın Eğilimi: Belçika, Fransa, İngiltere ve Türkiye'de, Ankara, TODAİE.

OYTAN, Muammer (1984), "Fransa'da İdarenin Politize Olmasını Önleyen Bir Organ: Bakanlık Kabinesi”, AİD, 17(1).

ÖZER, Mehmet Akif ve ÖZMEN, Burak (2017), "Parlamenter ve Başkanlık Sistemleri Arasında Konumunu Arayan Bürokrasi”, Strategic Public Management Journal, 3.

PEKER, Ömer ve AYTÜRK, Nihat (2000), Etkili Yönetim Becerileri, Ankara, Yargı Yay.

PIERRE, Jon (1995a), Bureaucracy In The Modern State: An Introduction To Comparative Public Administration, England, Edward Elgar.

Peters, B. Guy (2001), Politics of Bureaucracy, London \& NY, Routledge.

PETERS, B. Guy \& PIERRE, Jon (2004), "Politicization of the Civil Service: Concepts, Causes, Consequences", B. Guy Peters \& Jon Pierre (ed.), The Politicizaiton of the Civil Service in Comparative Perspective: The Quest for Control, London \& NY, Routledge / Taylor \& Francis Group.

PETERS, B. Guy (2010), The Politics of Bureaucracy: An Introduction to Coparative Public Administration, London \& NY, Routledge.

PIERRE, Jon (1995). "Conclusions: A Framework of Comparative Public Administration". J. Pierre (ed.). Bureaucracy in the Modern State. Cheltanham: Edward Elgar.

RIGGS, Fred W. (1994), "Bureaucracy: A Profound Puzzle for Presidentialism”, Ali Farazmand (ed.), Handbook of Bureaucracy, NY, Marcel Dekker Inc.

RIGGS, Fred W. (1997), “Coups and Crashes: Lessons for Public Administration”, A. Farazmand (ed.), Modern Systems of Government: Exploring the Rote of Bureaucrats and Politicians, California, Sage.

RIPLEY, Randall B. \& FRANKLIN, Grace A. (1982), Bureaucracy and Policy Implementation, Illionis, The Dorsey Press.

ŞAYLAN, Gencay (1976), “Günümüz Mülki Amirlik Sistemini Nitelendiren Eğilim: Siyasal-Yönetsel Yapı Bütünleşmesi”, Kurthan Fişek (ed.). "Türkiye'de Mülki İdare Amirliği: Sistem ve Sorunlar”, Ankara, TíD Yay.

ŞAYLAN, Gencay (1986), Türkiye’de Kapitalizm ve Siyasal İdeoloji, Ankara, TODAİE.

TATAROĞLU, Muhittin (2006), "Parlamenter ve Başkanlık Sistemlerinde Siyasi İktidar ve Bürokrasi İlişkileri ve Türkiye Açısından Bir Değerlendirme”, Yönetim Ve Ekonomi Dergisi, 13(1).

TORUN, Yeşer (2009), “Meritokrasi: Adaletin Terazisi mi Yoksa Bir Adalet İllüzyonu mu?”, Eğitim Bilim Toplum Dergisi, 7(26)

TUTUM, Cahit (1976), “Yönetimin Siyasallaşması ve Partizanlık”, AİD, 9(4).

UÇMAN, Hamit (2014), Türkiye'de Bürokrasi ve Siyaset, Ankara, Alter Yay.

ÜN, Lütfullah (2020), “Türkiye'de Hükümet Sistemlerinin Kamu Yönetimine Etkileri Bağlamında Cumhurbaşkanlığı Hükümet Sistemi”, Yayınlamış Doktora Tezi, Ondokuzmayıs Üniversitesi, Lisansüstü Eğitim Enstitüsü, Samsun.

WEBER, Max (1993), Sosyoloji Yazıları, Taha Parla (çev.), İstanbul, Hürriyet Vakfı Yay.

WILSON, Woodrow (1961), Seçme Parçalar, Nermin Abadan (çev.), Yenilik Basımevi.

WORLD BANK, Policy Research Working Paper, (4978). 